\title{
I-DISTANCE AND SEPARABILITY COEFFICIENT IN BUSINESS EVALUATION OF SME'S IN AGRIBUSINESS ${ }^{1}$
}

\author{
Blaženka Popović2 , Slobodan Ceranić ${ }^{3}$ Tamara Paunović ${ }^{4}$
}

\begin{abstract}
Summary
Systematic and continuous process of measuring and comparing business results of companies regarding to business results of leaders, in order to obtain information that will help the company to take action to improve its performance, is in a function of improving business operations. Accordingly, the first objective of this paper is, based on the coefficient of separability, to determine which indicators of business conditions and business results have the greatest impact on differences in the business operations of the observed SMEs operating in the food industry. The second objective of this work is to make the ranking of companies based on the business conditions and business results using discriminant analysis (I-distance), and then, to determine the overall rank of companies using general ranking coefficient (Ker). The results show that companies are significantly separated according to business results rather than to business conditions, and in addition, the business results also had a crucial impact on the overall rank of each company.
\end{abstract}

Keywords: Agribusiness, SMEs, separability coefficient, I-distance.

JEL: $Q 13, C 38$.

1 Work is the result of research funded by the Ministry of Science and Technological Development of Serbia: "Development and application of new and traditional technologies in the production of competitive food products with added value for domestic and world markets - CREATE WEALTH FROM THE WEALTH OF SERBIA" .

2 Blaženka Popović Ph.D., Associate professor, University of Belgrade, Faculty of Agriculture, Nemanjina street no 6, 11080 Zemun, Republic of Serbia, Phone: + 38111 4413404, E-mail: blazenka@agrif.bg.ac.rs

3 Slobodan Ceranić Ph.D., Full professor, University of Belgrade, Faculty of Agriculture, Nemanjina street no 6, 11080 Zemun, Republic of Serbia, Phone: + 381114413416 , E-mail: ceranic@agrif.bg.ac.rs

4 Tamara Paunović B.Sc., Assistant, University of Belgrade, Faculty of Agriculture, Nemanjina street no 6, 11080 Zemun, Republic of Serbia, Phone: + 381114413405 , E-mail:tamara@agrif.bg.ac.rs

EP 2016 (63) 3 (1039-1052) 


\section{Introduction}

Optimal use of agricultural resources, increase in production volume, creating a stable market, increase in exports of agricultural and food products and the realization of an integrated agricultural, rural and regional development are the strategic goals for the agriculture development of the Republic of Serbia (Maletic et al., 2011). Achievement of the objectives is highly dependent on development level of small and medium entrepreneurship in agribusiness. In order to encourage the development of small and medium-sized enterprises in the agribusiness, it is necessary to provide appropriate conditions that will stimulate the development of this sector of the economy (Popovic et al., 2011).

Small and medium enterprises are the main source of employment and the driving force of most developed countries in the world, and therefore, they should have such importance and role in development of agribusiness, especially in rural areas of Serbia (Ceranic, 2004). There are 20 million enterprises in the EU, over $99 \%$ of which are SMEs. They provide 80 million jobs and contribute to $60 \%$ of gross domestic product of the European Union. SMSs provide two-thirds of private sector jobs in the EU.

Their importance is reflected in significant flexibility, but also in increasing the efficiency of inputs utilization. In other words, it is very important to determine the factors that affect the performance and business operations of the same companies, because these companies are mostly financed from their own revenues, with a little help of government (Popovic, 2008). Therefore, the paper used separability coefficient (resolving power coefficient) to determine which indicators of business conditions and business results have the greatest impact on the separation of the observed three groups of enterprises in food industry (meat industry, dairy industry and milling industry). In previous research, this coefficient proved to be a good measure of quantifying the separation of clusters of family farms in western Serbia according to the indicators of business conditions (Lakic, Maletic, 1998) and business results (Lakic, Maletic, 1999), as well as in the case of morphological differentiation of bees (Nedic et al., 2012).

In order to determine the overall rank of each company, the rank of each company is determined separately according to business conditions and according to business results using the I-distance. A key argument for using I-distance method is the ability of this method to aggregate the large number of variables into a single numerical value, which is a summary of performance measures of the observed objects. Therefore, this method is widely used in various studies for ranking: countries (Ivanovic, Fanchetti 1973, Ivanovic, 1973; Seke et al., 2013), municipalities (Popovic, Maletic, 2007), banks (Bulajić et al., 2011; Bulajić et al., 2011), universities (Jeremic et al., 2011a), sports competitions (Jeremic, Radojcic, 2010), companies (Radoijicic et al., 1998), health system of countries (Jeremic et al., 2011b, 2012). 


\section{Material and methods}

The study included 19 small and medium-sized enterprises in the food industry, 8 of them from the meat industry, 6 in the dairy processing and 5 in the bread-making industry. Representative indicators of business conditions $\left(\mathrm{X}_{\mathrm{i}}\right)$ and business results $\left(\mathrm{Y}_{\mathrm{i}}\right)$ are shown in Table 1.

One of the aims of this paper is that, based on the separability coefficient, determines the extent to which each of the indicators of the conditions and results, and together, contributes to separation of observed enterprises group. In the case of division of a statistical set into subsets based on multidimensional criteria, the question that arises is the extent to which each indicator affects the separation of elements into subsets (Ivanovic, 1977).

Table 1. The observed indicators of business conditions and business results

\begin{tabular}{|c|c|}
\hline Business conditions $\left(\mathbf{X}_{i}\right)$ & Business results $\left(\mathbf{Y}_{i}\right)$ \\
\hline $\mathrm{X}_{1}$ - Total capital & $\begin{array}{l}\mathrm{Y}_{1} \text { - Business income per } \\
\text { employee }\end{array}$ \\
\hline $\mathrm{X}_{2}$ - Original capital & $\mathrm{Y}_{2}-$ Sales income \\
\hline $\mathrm{X}_{3}$ - Number of employees & $\begin{array}{l}\mathrm{Y}_{3}-\text { Business expenses per } \\
\text { employee }\end{array}$ \\
\hline $\begin{array}{l}\mathrm{X}_{4}-\text { Real property, existing } \\
\text { equipment and biological assets }\end{array}$ & $\begin{array}{l}\mathrm{Y}_{4}-\text { Depreciation costs and } \\
\text { provision }\end{array}$ \\
\hline $\mathrm{X}_{5}-$ Stocks & $Y_{5}-$ Business profit \\
\hline $\mathrm{X}_{6}$ - Business assets & $\begin{array}{l}Y_{6}-\text { Profit from operating activities } \\
\text { before tax }\end{array}$ \\
\hline $\mathrm{X}_{7}$ - Fixed liabilities & $Y_{7}-$ Financial incomes \\
\hline $\mathrm{X}_{8}$ - Fixed assets per employee & $\mathrm{Y}_{8}$ - Financial expenses \\
\hline $\mathrm{X}_{9}$ - Current assets per employee & $Y_{9}-$ Net profit per employee \\
\hline
\end{tabular}

Source: Author's choice of indicators

Separability coefficients used in this study, are differ in their shape, depending on the number of given subsets that were separated.

Partial separability coefficient of two subsets compared the characteristic $X_{p}$, can be shown as follows (Erdeljan et al.,1974): 


$$
\sigma_{p}^{2}=\frac{n_{r} n_{k}\left|\bar{X}_{r}-\bar{X}_{k}\right|}{\sum_{i=1}^{n_{k}} \sum_{j=1}^{n_{r}}\left|x_{k i}-x_{r j}\right|}
$$

where the group of companies are marked with $\mathrm{R}$ and $\mathrm{K}$, their indicators are $\mathrm{X}_{\mathrm{ki}}$ and $\mathrm{X}_{\mathrm{rj}}$, the corresponding averages of these indicators are $\bar{X}_{r}$ and $\bar{X}_{k}$, and the feature volumes are $n_{r}$ and $n_{k}$. Partial separability coefficient of "s" subset compared the characteristic $X_{p}$, can be shown as follows:

$$
\sigma_{p}^{s}=\frac{\sum_{k=1}^{s} \sum_{r>k}^{s} n_{r} n_{k}\left|\bar{X}_{r}-\bar{X}_{k}\right|}{\sum_{k=1}^{s} \sum_{r>k}^{s} \sum_{i=1}^{n_{k}} \sum_{j=1}^{n_{r}}\left|x_{k i}-x_{r j}\right|}
$$

The separability coefficient for "s" subsets with respect to $\mathrm{m}$ indicators is given as a geometric mean of partial separability coefficient for one feature:

$$
\sigma_{(m)}^{s}=\sqrt[m]{\sigma_{1}^{s} \cdot \sigma_{2}^{s} \cdot \ldots \cdot \sigma_{m}^{s}}
$$

Separability coefficient varies in the range of $[0,1]$. If the value of the coefficient is closer to 1 , then the greater is the separation, if it is close to 0 , then the mutually overlapping of subsets is getting stronger, and therefore should be considered as a subset created by the integration of two or more subsets.

The above patterns are used to find out to what extent observed enterprises are separated compared to indicators of business conditions and business results.

In order to determine the ranking list of observed enterprises (sequential classification) based on a selected set of features, I-distance method is used. I-distance is a metric in n-dimensional space. A key argument for using I-distance method is its ability to synthesize a large number of variables into a single numerical value (Ivanovic, 1963). This is particularly useful for the variables that are shown in different measuring units. For a selected set of variables $X^{T}=\left(X_{1}, X_{2}, \ldots X_{K}\right)$ chosen to characterize the entities, the I-distance between the two entities $e_{r}=\left(X_{1 r}, X_{2 r}, \ldots, X_{k 1}\right)$ and $e_{s}=\left(X_{1 s}, X_{2 s}, \ldots, X_{k s}\right)$ is defined as:

$$
D(r, s)=\sum_{i=1}^{k} \frac{\left|d_{i}(r, s)\right|}{\sigma_{i}} \prod_{j=1}^{i-1}\left(1-r_{i j}\right)
$$

where $d_{i}(r, s)$ is the distance between the values of variable $\mathrm{X}_{\mathrm{i}}$ for er and es, e.g., the discriminate effect,

$$
d_{i}(r, s)=\left|x_{i r}-x_{i r}\right| \quad i \in\{1, \ldots, k\}
$$


$\sigma_{i}$ the standard deviation of $x_{i}$, and $r_{j i .12} \cdots_{\mathrm{j}-1}$ is a partial coefficient of the correlation between $x_{i}$ and $x_{j},(j<i)$, (Ivanović, 1973).

The construction of the I - distance is iterative; it is calculated through the following steps:

- Calculate the value of the discriminate effect of the variable $X_{1}$ (the most significant variable, that which provides the largest amount of information on the phenomena that are to be ranked).

- Add the value of the discriminate effect of $X_{2}$ which is not covered by $X_{1}$.

- Add the value of the discriminate effect of $X_{3}$ which is not covered by $X_{1}$ and $X_{2}$.

- Repeat the procedure for all variables (Mihailovic et al., 2009).

Sometimes it is not possible to establish the same sign for all variables, and therefore may appear negative correlation coefficient and negative partial correlation coefficient. That is why I-squared distance is often used and it is defined as:

$$
D^{2}(r, s)=\sum_{r=1}^{k} \frac{d_{i}^{2}(r, s)}{\sigma_{i}^{2}} \prod_{j=1}^{i-1}\left(1-r_{j i: 1,2, j-1}^{2}\right)
$$

The overall rank coefficient $\left(K_{e r}\right)$ is the ratio of the calculated values of I-distance for the criteria of results $\left(D_{r}\right)$ and values of I- distance for the criteria of business conditions $\left(D_{u}\right)$

$$
K_{e r}=\frac{D_{r}}{D_{u}}
$$

Based on calculated I-distance, mutual distance matrices, which contain information necessary for objective classification, are formed. Ranking list of elements of the set $\mathrm{P}$ is obtained when all the elements of the set $\mathrm{P}$ align according to size of the calculated I-distance. This ranking list shows the rank of each element, but also gives the difference in distances between the individual elements.

I squared-distance is used to determine the ranking of enterprises according to business conditions. Business results were also examined, and the rank is defined based on these results. Based on business conditions and business results, the overall ranking of enterprises $\left(K_{\mathscr{e}}\right)$ is determined.

Furthermore, based on this method, managers can be successfully provided with information relating to efficient and fast decision making, to direct production process and to rationally use economic conditions, in order to maximize profits.

\section{The research results}

In order to achieve its aim, incremental analysis were used, first of all, using the calculation of partial separability coefficient differences between the group of enterprises 
came expressed, based on individual performance and based on separability power of themselves. Separability power of all the features simultaneously is demonstrated by calculating total separability coefficient.

The obtained results of business conditions (Table 2.) show that the subset of enterprises that processed meat make medium separation from dairy in relation to indicators $\mathrm{X}_{7}$ (fixed liabilities) and $\mathrm{X}_{8}$ (fixed assets per employee), and minimum separation is to business assets (0.0223) and original capital (0.0407). If comparing enterprises that processed meat and bakery, the greatest separation is observed in business assets (0.4861) and stocks (0.4523), and lowest value of 0.0310 is with indicator $\mathrm{X}_{4}$ (real estate-property, existing equipment and biological assets). Subsets of dairies and bakeries are mostly separated by the value of total capital (0.6453) and current assets per employee (0.5880). These two subsets are least separated compared to the value of original capital and number of employees.

Table 2. Partial separability coefficients for business conditions

\begin{tabular}{|c|cccc|}
\hline & \multicolumn{3}{|c|}{$\sigma_{p}^{2}$} & $\sigma_{p}^{3}$ \\
\cline { 2 - 5 } & $\begin{array}{c}\text { meat } \\
\text { processing- } \\
\text { dairies }\end{array}$ & $\begin{array}{c}\text { meat } \\
\text { processing- } \\
\text { bakeries }\end{array}$ & $\begin{array}{c}\text { dairies- } \\
\text { bakeries }\end{array}$ & $\begin{array}{c}\text { meat processing- } \\
\text { dairies-bakeries }\end{array}$ \\
\hline $\mathrm{X}_{1}$ & 0.0980 & 0.3546 & 0.6453 & 0.3134 \\
$\mathrm{X}_{2}$ & 0.0407 & 0.0598 & 0.0343 & 0.0469 \\
$\mathrm{X}_{3}$ & 0.3445 & 0.3900 & 0.0860 & 0.3237 \\
$\mathrm{X}_{4}$ & 0.2436 & 0.0310 & 0.3126 & 0.1768 \\
$\mathrm{X}_{5}$ & 0.1198 & 0.4523 & 0.4004 & 0.2714 \\
$\mathrm{X}_{6}$ & 0.0223 & 0.4861 & 0.4207 & 0.3003 \\
$\mathrm{X}_{7}$ & 0.5666 & 0.3849 & 0.1256 & 0.4036 \\
$\mathrm{X}_{8}$ & 0.5363 & 0.3664 & 0.3441 & 0.4426 \\
$\mathrm{X}_{9}$ & 0.4142 & 0.2178 & 0.5880 & 0.3984 \\
\hline \hline
\end{tabular}

Source: Author's calculations

Comparative observation of calculated partial coefficients allows certain generalizations. Subset of enterprises that processed meat is separated from the other 
two subsets by number of employees and fixed liabilities, dairies by indicator $\mathrm{X}_{4}$ (property, existing equipment and biological assets) and bakeries are separated from the other two subsets by indicators $\mathrm{X}_{1}$ (total capital) and $\mathrm{X}_{6}$ (business assets).

Partial separability coefficient $\left(\sigma_{p}^{3}\right)$ of these three subsets, compared to characteristic $\mathrm{X}_{\mathrm{p}}$, shows that the maximum value is calculated for indicator $\mathrm{X}_{8}$ (fixed assets per employee), so therefore, this indicator contributes most to a separation of these three subsets. All three subsets are least separated by value of original capital.

Separation of enterprises that processed meat, dairies and bakeries for all nine indicators of business conditions, at the same time is very low $\sigma_{(m)}^{3}=0.2569$, indicating that these three subsets are slightly different regarding business conditions, or that their business conditions are very similar.

Separation of observed enterprises subsets for all nine indicators of business results, at the same time is $\sigma_{(m)}^{3}=0.4841$, suggesting that these three subsets are more separated by results than by business conditions.

Table 3. Partial separability coefficients for business results

\begin{tabular}{||c|cccc|}
\hline \hline \multirow{2}{*}{$\begin{array}{c}\text { meat } \\
\text { processing- } \\
\text { dairies }\end{array}$} & $\begin{array}{c}\sigma_{p}^{2} \\
\text { meat processing- } \\
\text { bakeries }\end{array}$ & dairies-bakeries & $\begin{array}{c}\sigma_{p}^{3} \\
\text { meat } \\
\text { processing- } \\
\text { dairies-bakeries }\end{array}$ \\
\hline $\mathrm{Y}_{1}$ & 0.8354 & 0.5791 & 0.9759 & 0.8037 \\
$\mathrm{Y}_{2}$ & 0.8970 & 0.0181 & 0.9556 & 0.6043 \\
$\mathrm{Y}_{3}$ & 0.9274 & 0.5382 & 0.9878 & 0.8343 \\
$\mathrm{Y}_{4}$ & 0.2288 & 0.6907 & 0.4619 & 0.4577 \\
$\mathrm{Y}_{5}$ & 0.2611 & 0.1660 & 0.0821 & 0.1811 \\
$\mathrm{Y}_{6}$ & 0.6939 & 0.6370 & 0.0577 & 0.4877 \\
$\mathrm{Y}_{7}$ & 0.1745 & 0.1909 & 0.5780 & 0.2540 \\
$\mathrm{Y}_{8}$ & 0.8162 & 0.1850 & 0.7905 & 0.5866 \\
$\mathrm{Y}_{9}$ & 0.8143 & 0.8039 & 0.1186 & 0.5981 \\
\hline
\end{tabular}

\section{Source: Author's calculations}

The separation level of dairies and bakeries is extremely high for the following indicators: business expenses per employee (0.9878), business income per employee (0.9759) and sales income (0.9556). The situation is similar with enterprises that processed meat and dairies $\left(\mathrm{Y}_{3}-0.9274, \mathrm{Y}_{2}-0.8970\right.$ and $\left.\mathrm{Y}_{1}-0.8354\right)$. The largest separation between 
dairies and bakeries is in net profit per employee (0.8039). Based on calculated partial separability coefficients $\left(\sigma_{p}^{2}\right)$, it can be concluded that in a large number of indicators dairies are well separated from meat processors and bakeries, while a slightly lower level of separation is between enterprises that processed meat and bakeries (Table 3.).

Partial separability coefficients $\left(\sigma_{p}^{3}\right)$ that are calculated, indicate that the separation of these three subsets of enterprises is most affected by business expenses per employee (0.8343), business income per employee (0.8037), sales income $(0.6043)$, net profit per employee (0.5981) and financial expenses $(0.5866)$. When it comes to business results, business profit $(0.1811)$ and financial income $(0.2540)$ have the least impact on the separation of these three subsets.

In order to better comprehend the business differences between observed enterprises, their ranking is done based on actual business conditions and results (Table 4.). This list, in addition to rank of each enterprise, also gives the difference in distances between individual enterprises, which is a very important indicator.

Table 4. The results of I-squared distances and ranks of enterprises according to Idistance

\begin{tabular}{|c|c|c|c|c|c|c|}
\hline \multirow[b]{2}{*}{ Enterprises } & \multicolumn{2}{|c|}{$\begin{array}{c}\text { Business } \\
\text { conditions }\end{array}$} & \multicolumn{2}{|c|}{$\begin{array}{c}\text { Business } \\
\text { results }\end{array}$} & \multirow{2}{*}{$\begin{array}{c}\begin{array}{c}\text { Rank } \\
\text { coefficient }\end{array} \\
K_{\text {er }}\end{array}$} & \multirow{2}{*}{$\begin{array}{c}\text { Rank } \\
\text { according } \\
\text { to } K_{\text {er }}\end{array}$} \\
\hline & $\begin{array}{c}\text { I - } \\
\text { distance } \\
\text { value }\end{array}$ & Rank & $\begin{array}{c}\text { I - } \\
\text { distance } \\
\text { value }\end{array}$ & Rank & & \\
\hline Meat processing I & 6.85 & 1 & 25.42 & 9 & 3.7109 & 19 \\
\hline Meat processing II & 46.02 & 18 & 41.16 & 18 & 0.8944 & 12 \\
\hline Meat processing III & 39.67 & 10 & 35.85 & 13 & 0.9037 & 14 \\
\hline Meat processing IV & 37.50 & 8 & 12.02 & 1 & 0.3205 & 1 \\
\hline Meat processing $\mathrm{V}$ & 45.13 & 17 & 36.32 & 14 & 0.8048 & 9 \\
\hline Meat processing VI & 44.78 & 16 & 40.70 & 17 & 0.9089 & 15 \\
\hline Meat processing VII & 33.80 & 6 & 22.02 & 6 & 0.6515 & 6 \\
\hline Meat processing VIII & 42.22 & 13 & 26.56 & 10 & 0.6291 & 5 \\
\hline Dairy I & 44.04 & 15 & 35.61 & 12 & 0.8086 & 10 \\
\hline Dairy II & 42.47 & 14 & 42.74 & 19 & 1.0064 & 18 \\
\hline Dairy III & 19.74 & 2 & 16.57 & 4 & 0.8394 & 11 \\
\hline Dairy IV & 29.68 & 4 & 29.37 & 11 & 0.9896 & 17 \\
\hline
\end{tabular}




\begin{tabular}{||l|c|c|cccc|}
\hline \multirow{2}{*}{ Enterprises } & \multicolumn{2}{|c|}{$\begin{array}{c}\text { Business } \\
\text { conditions }\end{array}$} & \multicolumn{2}{c|}{$\begin{array}{c}\text { Business } \\
\text { results }\end{array}$} & $\begin{array}{c}\text { Rank } \\
\text { coefficient }\end{array}$ & $\begin{array}{c}\text { Rank } \\
\text { according } \\
\text { to K }\end{array}$ \\
\cline { 2 - 7 } & $\begin{array}{c}\text { I - } \\
\text { distance } \\
\text { value }\end{array}$ & Rank & $\begin{array}{c}\text { I - } \\
\text { distance } \\
\text { value }\end{array}$ & Rank & K $_{\text {er }}$ & f $^{*}$ \\
\hline Dairy V & 47.54 & 19 & 38.24 & 16 & 0.8044 & 8 \\
Dairy VI & 41.07 & 12 & 21.36 & 5 & 0.5201 & 4 \\
Bakery I & 33.86 & 7 & 22.57 & 7 & 0.6666 & 7 \\
Bakery II & 26.60 & 3 & 23.84 & 8 & 0.8962 & 13 \\
Bakery III & 30.47 & 5 & 13.06 & 2 & 0.4286 & 3 \\
Bakery IV & 38.12 & 9 & 15.99 & 3 & 0.4195 & 2 \\
Bakery V & 39.73 & 11 & 37.34 & 15 & 0.9398 & 16 \\
\hline
\end{tabular}

Source: Author's calculations

Based on the presented classification of enterprises it can be noticed that the enterprises with the best conditions (range 1-3) realized lower results, which is also indicated in range coefficients 9,4 and 8 . It can be concluded that the available conditions are not adequately used, as illustrated by general (total) range coefficient 19, 11 and 13. The I distance value for business conditions in enterprises with range 1 (6.85) is almost three times less than the following I - distance values (range 2 - 19.74), which indicates that the enterprise has a most favorable business conditions, but achieves average results, which leads him to the last place according to business success $\left(K_{*}-19\right)$.

Enterprises that have had medium business conditions among the observed enterprises (ranks 8, 9 and 5), but the best business results (ranks 1,3, and 2) take up the best places in the general ranking $\left(K_{e}-1,2\right.$ and 3$)$.

After that, our set of data is further analyzed, and the correlation coefficient of each indicator with the value of I-distance was calculated and presented in Table 5. and Table 6. (Pearson correlations were used). This is one of the key parts of the work, since it provides information on the importance of each indicator for the ranking process (Jeremić, 2012). 
Table 5. Correlations of input indicators of business conditions with I-distance

\begin{tabular}{||cc||}
\hline \multicolumn{1}{|c|}{ Indicators of business conditions } & $\mathbf{r}$ \\
\hline $\mathrm{X}_{2}$ - Original capital & $0.83^{* *}$ \\
$\mathrm{X}_{4}$ - Property, existing equipment and biological assets & $0.80^{* *}$ \\
$\mathrm{X}_{8}$ - Fixed assets per employee & $0.78^{* *}$ \\
$\mathrm{X}_{7}$ - Fixed liabilities & $0.70^{* *}$ \\
$\mathrm{X}_{1}$ - Total capital & $0.62^{* *}$ \\
$\mathrm{X}_{9}-$ Current assets per employee & $0.62^{* *}$ \\
$\mathrm{X}_{5}-$ Stocks & $0.58^{* *}$ \\
$\mathrm{X}_{6}-$ Business assets & $0.37^{\mathrm{ns}}$ \\
$\mathrm{X}_{3}-$ Number of employees & $0.07^{\mathrm{ns}}$ \\
\hline
\end{tabular}

Source: Author's calculations $* * \mathrm{p}<0.01,{ }^{*} \mathrm{p}<0.05$, ${ }^{\mathrm{ns}}$ not significant

As the results show (Table 5.), the most important indicator in enterprises ranking by business conditions is original capital with the correlation coefficient $r=0.83(p<0.01)$, closely followed by the property, existing equipment and biological assets, $r=0.80$ $(\mathrm{p}<0.01)$. The least impact on the enterprises ranking by business conditions had a number of employees $(\mathrm{r}=0.07$ and $\mathrm{p}>0.05)$.

Table 6. Correlations of input indicators of business results with I - distance

\begin{tabular}{||cc||}
\hline Indicators of business results & $\mathbf{r}$ \\
\hline $\mathrm{Y}_{5}$ - Business profit & $0.80^{* *}$ \\
$\mathrm{Y}_{9}$ - Net profit per employee & $0.74^{* *}$ \\
$\mathrm{Y}_{6}$ - Profit from operating activities before tax & $0.71^{* *}$ \\
$\mathrm{Y}_{2}$ - Revenues from sales & $0.68^{* *}$ \\
$\mathrm{Y}_{1}$ - Business income per employee & $0.68^{* *}$ \\
$\mathrm{Y}_{3}$ - Business expenses per employee & $0.64^{* *}$ \\
$\mathrm{Y}_{4}$ - Depreciation and amortization & $0.57^{* *}$ \\
$\mathrm{Y}_{8}$ - Financial expenses & $0.41^{\mathrm{ns}}$ \\
$\mathrm{Y}_{7}-$ Financial incomes & $0.36^{\mathrm{ns}}$ \\
\hline
\end{tabular}

Source: Author's calculations $\quad * * \mathrm{p}<0.01,{ }^{*} \mathrm{p}<0.05,{ }^{\text {ns }}$ not significant

In business results (Table 6.), the most important feature for ranking enterprises is business profit with a correlation coefficient $r=0.80(p<0.01)$, and net profit per employee $(\mathrm{r}=0.74, \mathrm{p}<0.01)$, as well as profit from operating activities before tax $(\mathrm{r}=$ 
$0.71, \mathrm{p}<0.01)$. The results obtained are as expected, given that the profit is one of the most important indicators of the financial performance of each enterprise. Financial expenses and financial incomes had no statistically significant effect in the ranking of enterprises according to the business results $(\mathrm{p}>0.05)$.

\section{Discussion}

Enterprises in the field of agro-industrial complex, as well as the overall economy in the last decade were operating under very unfavorable, as it were "impossible", conditions. The consequence of this situation is a great impoverishment of the majority of enterprises, which is clearly reflected in marked decrease of both natural and financial parameters of success.

The research results indicate that the observed enterprises are significantly more separated in achieved results rather than in business conditions. The results obtained by using the separability coefficients were also confirmed by using the method of I - distance, because the achieved business results had more effect on overall ranking of enterprises, rather than business conditions. According to the business results, a significant separation of dairies subset on the one side, and remaining two on the other, can be noticed. After using the method of I - distance, it can be concluded that, on average, dairies achieved the worst results, which also confirms the results obtained using the separability coefficient.

Enterprises that have had lower business conditions have worked better, have better use of resources and have achieved better economic results. At the same time, enterprises that have a more favorable business conditions have not achieved adequate production results, because the available resources are not used properly.

The research results indicate that there are significant reserves in the internal economy for business improvement and competitiveness through rational use of all the available conditions. By optimizing the production structure and production assortment, by rational use of resources and by minimizing operating expenses managers can improve the internal economy and increase the competitiveness of its enterprises (Popovic et al., 2008). Appropriate measures of economic policy are also necessary in order to create such economic conditions that are essential for successful market operation and development of SMEs in agribusiness.

\section{Literature}

1. Bulajić, M., Savić, G., Savić, S., Mihailović, N., Matrić, M. (2011): Efficiency assessment of banks in Serbia. TTEM - Technics Technologies Education Management, Vol. 6, No. 3, pp. 657-662.

2. Bulajic, M., Knezevic, S., Jeremic, V., Zarkic Joksimovic, N. (2012): Towards a Framework for Evaluating Bank Efficiency. International Journal of Agricultural and Statistical Sciences, Vol. 8, No. 2, pp. 377-384.

3. Ceranić, S. (2004): Management in small and medium-sized enterprises. Textbook, 
Belgrade: Faculty of Small and Medium Sized Enterprises.

4. Erdeljan, V., Mikelić, M., Stanković, J. (1974): Koeficijent moći razdvajanja u analizi nekih indikatora proizvodnje društvenih poljoprivrednih gazdinstava. XI godišnji sastanak Jugoslovenskog statističkog društva, Zlatibor.

5. Ivanović, B. (1963): Discriminant analysis. Belgrade: Scientific Book.

6. Ivanovic, B. (1973): A method of establishing a list of development indicators. Paris: United Nations educational, scientific and cultural organization.

7. Ivanovic, B., Fanchette, S. (1973): Grouping and ranking of 30 countries of SubSaharan Africa, Two distance-based methods comp ared. Paris: United Nations educational, scientific and cultural organization.

8. Ivanović, B. (1977): Classification Theory. Belgrade: Institute for Industrial Economic.

9. Jeremic, V., Bulajic, M., Martic, M., Radojicic, Z. (2011a): A fresh approach to evaluating the academic ranking of world universities. Scientometrics, 87(3), 587596. doi:10.1007/s11192-011-0361-6

10.Jeremić, V. (2012): Statistički model efikasnosti zasnovan na ivanovićevom odstojanju,doktorska disertacija, FON, Beograd, Srbija.

11.Jeremić, V., Seke, K., Radojičić, Z., Jeremić, D., Marković, A., Slović, D., Aleksić, A. (2011b): Measuring health of countries: a novel approach. HealthMED, Vol. 5, No. 6, 1762-1766.

12.Jeremić, V., Bulajić, M., Martić, M., Marković, A., Savić, G., Jeremić, D., Radojičić, Z. (2012). An Evaluation of European Countries Health Systems through Distance Based Analysis. Hippokratia, Vol. 16, No. 2, pp. 170-174.

13.Jeremic, V., Radojicic, Z. (2010): A New Approach in the Evaluation of Team Chess Championships Rankings. Journal of Quantitative Analysis in Sports, Vol. 6, no. 3, doi:10.2202/1559-0410.1257

14.Lakić, N., Maletić, R. (1999): Stepen razdvajanja izdvojenih klastera na osnovu indikatora rezultata proizvodnje, Journal of Agricultural Sciences, vol. 44, no. 1, pp. 89-97.

15.Maletić, R., Ceranić, S., Popović, B. (2011): Small and medium enterprises as factors in reducing poverty in rural communities Serbian. Economics of Agriculture, Vol. 57, No. 1, pp. 121-132.

16.Mihailović, N., Bulajić, M., Savić, G. (2009): Ranking of banks in Serbia. Yugoslav Journal of Operations Research, Vol. 19, No. 2, pp. 323-334. doi:10.2298/ YUJOR0902323M.

17.Popović, B. (2008): Contribution of small and medium sized enterprises in development of agribusiness in Republic of Serbia, $\mathrm{PhD}$ thesis, Faculty of Agriculture, Zemun.

18.Popović, B., Maletić, R. (2007): Ranking of municipalities of the Republic of Serbia 
based on small and medium agrobusinesses, International scientific meeting: «Multifunctional agriculture and rural development», Thematic Procceedings, Belgrade -Beočin, 2007., ISBN 978-86-82121-47-3, COBISS.SR-ID 145178124, pp. 1113-1119.

19.Popović, B., Maletić, R., Paunović, T. (2008): Development of small and medium size enterprises in function of competitiveness promotion in agribusiness. Proceedings of the International Scientific Conference: Multifunctional Agriculture and Rural Development. 4-5 december 2008, Belgrade, pp. 76-82.

20.Popović, B., Maletić, R., Ceranić, S., Paunović, T., Janković, Šoja, S. (2011): Defining homogenous areas of Serbia based on development of SME in agribusiness using the cluster analysis. TTEM - Technics Technologies Education Management, Vol. 6, No. 3, pp. 811-818.

21.Radojičić, Z., Stefanović, T., Vukmirović, D. (1998): Rangiranje preduzeća metodom Ivanovićevog odstojanja, Analiza grupisanja IV, SZS, Kosmaj.

22.Seke, K., Petrovic, N., Jeremic, V., Vukmirovic, J., Kilibarda, B., Martic, M. (2013): Sustainable development and public health: rating European countries. BMC Public Health, 13, 77. doi:10.1186/1471-2458-13-77 


\title{
PRIMENA I - ODSTOJANJA I KOEFICIJENTA SEPARABILNOSTI U OCENI POSLOVANJA MSP U AGROBIZNISU
}

\section{Blaženka Popovićc ${ }^{5}$ Slobodan Ceranićc, Tamara Paunovic ${ }^{7}$}

\begin{abstract}
Sažetak
Sistematski i kontinuirani proces merenja i upoređivanja poslovnih rezultata preduzeća u odnosu na poslovne rezultate lidera radi dobijanja informacija kojeće pomoći preduzeću da preduzme akcije za poboljšanje svojih performansi je u funkciji unapređenja poslovanja. S tim u vezi je postavljen i prvi cilj rada, a to je da se primenom koeficijenta separabilnosti utvrdi koji pokazatelji uslova i rezultata poslovanja najviše utiču na razlike u poslovanju posmatranih MSP iz prehrambene industrije. Drugi cilj rada je da se primenom diskriminacione analize (I-odstojanja) izvrši rangiranje preduzeća na osnovu uslova kao i rezultata poslovanja, a zatim da se pomoću opšteg koeficijanta ranga $\left(K_{e p}\right)$ odredi opšti rang preduzeća. Rezultati analize pokazuju da se preduzeća značajnije razdvajaju prema rezultatima nego prema uslovima poslovanja, a rezultati poslovanja su takođe presudno uticali na opšti rang svakog preduzeća.
\end{abstract}

Ključne reči: Agrobiznis, MSP, koeficijent separabilnosti, I - odstojanje

5 Vanredni profesor, dr Blaženka Popović, Univerzitet u Beogradu, Poljoprivredni fakultet, Nemanjina ulica br. 6, Zemun, Republika Srbija, Telefon: + 38111 4413404, e-mail: blazenka@agrif.bg.ac.rs

6 Redovni profesor, dr Slobodan Ceranić, Univerzitet u Beogradu, Poljoprivredni fakultet, Nemanjina ulica br. 6, Zemun, Republika Srbija, Telefon: + 38111 4413416, e-mail: ceranic@agrif.bg.ac.rs

7 Asistent, dipl. inž.Tamara Paunović, Univerzitet u Beogradu, Poljoprivredni fakultet, Nemanjina ulica br. 6, Zemun, Republika Srbija, Telefon: + 38111 4413405, e-mail: tamara@agrif.bg.ac.rs 